\title{
Ectopic expression of microRNA-155 enhances innate antiviral immunity against HBV infection in human hepatoma cells
}

\author{
Chenhe Su, Zhaohua Hou, Cai Zhang, Zhigang Tian and Jian Zhang*
}

\begin{abstract}
Background: Host innate antiviral immunity is the first line of defense against viral infection, and is precisely regulated by thousands of genes at various stages, including microRNAs. MicroRNA-155 (miR-155) was found to be up-regualted during viral infection, and influence the host immune response. Besides, the expression of miR-155, or its functional orthologs, may also contribute to viral oncogenesis. HBV is known to cause hepatocellular carcinoma, and there is evidence that attenuated intracellular immune response is the main reason for HBV latency. Thus, we assume miR-155 may affect the immune response during HBV infection in human hepatoma cells.

Results: We found that ectopic expression of miR-155 upregulated the expression of several IFN-inducible antiviral genes in human hepatoma cells. And over-expression of miR-155 suppressed suppressor of cytokine signaling 1 (SOCS1) expression and subsequently enhanced signal transducers and activators of transcription1 (STAT1) and signal transducers and activators of transcription3 (STAT3) phosphorylation. We further demonstrate that ectopic expression of miR-155 inhibits HBV $X$ gene expression to some extent in vitro.
\end{abstract}

Conclusion: MiR-155 enhances innate antiviral immunity through promoting JAK/STAT signaling pathway by targeting SOCS1, and mildly inhibits HBV infection in human hepatoma cells.

Keywords: miR-155, HBV, anti-virus, hepatoma cells, innate immunity

\section{Background}

MicroRNAs (miRNA) are a class of highly conserved short noncoding RNAs originate from genome of eukaryotic organisms and even kinds of virus. MiRNAs have emerged as a major class of post-transcriptional geneexpression regulators and are involved in a wide variety of biological processes. They regulate target gene expression mainly through imperfectly base pairing with the 3' -untranslated regions (3'-UTRs) of target mRNAs in animals, preventing protein accumulation by inducing mRNA degradation or suppressing translation [1,2].

Recent researches demonstrate that many miRNAs, such as miR-146a, miR-155 and miR-223, play important roles in innate immune response at various phases in vertebrates [3]. In order to eliminate virus immediately after infection, host-encoded miRNAs can directly

\footnotetext{
* Correspondence: zhangj65@sdu.edu.cn

School of Pharmaceutical Sciences, Shandong University, Jinan 250012, China
}

(c) 2011 Su et al.; licensee BioMed Central Ltd. This is an open access article distributed under the terms of the Creative Commons Attribution License (http://creativecommons.org/licenses/by/2.0), which permits unrestricted use, distribution, and reproduction in any medium, provided the original work is properly cited. miRNAs can not only evolve to regulate viral gene expression to accommodate life cycle and maintain latency [4], but also affect cellular gene expression by directly participating in host gene expression or by mimicking cellular miRNAs to hijack in unclear cellular regulatory networks. So, research on the roles of miRNA is an important pathway to reveal the "fighting" between pathogenic microorganism and their hosts.

Among all miRNAs discovered in Homo sapiens in miRBase Release 17, miR-155 is considered as one of the typical multifunctional miRNAs. MiR-155 is first found within the B cell integration cluster (BIC) on chromosome 21 in human genome. The genomic structure of human BIC consists of three exons, and miR-155 is located within the third exon [5]. To date, increasing evidence reveals that miR-155 is involved in numerous physiological and pathological processes including innate and adaptive immunity, inflammation and tumorigenesis 
[6]. Moreover, miR-155 was found to be induced by poly (I:C) and other TLR ligands through either MyD88 or TRIF dependent signaling pathways, and by IFN- $\beta$ and several cytokines such as IL-1 $\beta$ through TNF- $\alpha$ signaling.

Viruses may downregulate the expression of certain cellular miRNAs that are harmful for viral movement and may also upregulate some miRNAs that are rational for the virus. Although the benefit of miR-155 expression to viruses remains largely unknown, the expression of miR-155, or its functional orthologs, may contribute to viral oncogenesis, like KSHV [7] and MDV-1 [8] encoding a viral miR-155 ortholog while EBV instead induces expression of endogenous miR-155. However, till now, there are only a few reports about the roles of miR-155 in viral infection.

$\mathrm{HBV}$, which causes acute and always chronic HBV infection and leads to hepatoma fibrosis, cirrhosis and eventually hepatocellular carcinoma [9], has infected more than 350 million people and become a main threaten to public health across the world, especially in developing countries [10]. Modern immunology believed that impaired immune system, both intrinsic immune response and classical humoral/cellular immunity is the major reason for HBV latency, chronicity and reactivity, and many achieves have been made to explain the molecular mechanism upon this topic[11].

Based on all the outcomes have been made in this field, we become interested in the roles of miRNA in hepatocyte-HBV interactions. Though miR-155 level was very low in normal hepatocytes and several hepatoma cells lines, but it can be upregulated in certain pathological process, such as tumorigenesis. Considering that HBV can promote carcinomatous change in hepatocyte, it can be expected that miR-155 may be a unique molecular in HBV pathopoiesis. But until now there is no report about the role of miR-155 on the innate antiviral immunity in human hepatocytes or hepatoma cells.

In the present study, miR-155 was over-expressed in human hepatoma cells (HepG2, H7402), and we found that SOCS1 expression was suppressed and subsequently the phosphorylation STAT1 and STAT3 were enhanced, which resulted in the induction of IFN-inducible genes expression. Additionally, over-expression of miR-155 slightly increased the proliferation ability of HepG2 cells, while exhibited mild anti-HBV effect in human hepatoma cells. These findings reveal a new intricate physiological interplay between miRNAs and HBV replication.

\section{Results}

Over-expression of miR-155 in human hepatoma cells

To investigate the role of miR-155 in antiviral immune response in human hepatoma cells, we used two methods to over-express miR-155 in human hepatoma cells [12,13]. First, the plasmid pcDNA3-hsa-miR-155 was transfected into HepG2 cells using Lipofectamine 2000, and these cells were selected by G418 for two weeks. Levels of miR-155 in transfectant HepG2 cells (HepG2-miR155) were evaluated by qRT-PCR. As shown in Figure 1A, miR-155 level in HepG2-miR155 cells was significantly higher than that in parental HepG2 cells $(\sim 40$ folds $)(P<0.01)$. Next, miR-155 mimics or control RNA (cnt RNA) were transiently transfected into HepG2 cells. As shown in Figure 1B,

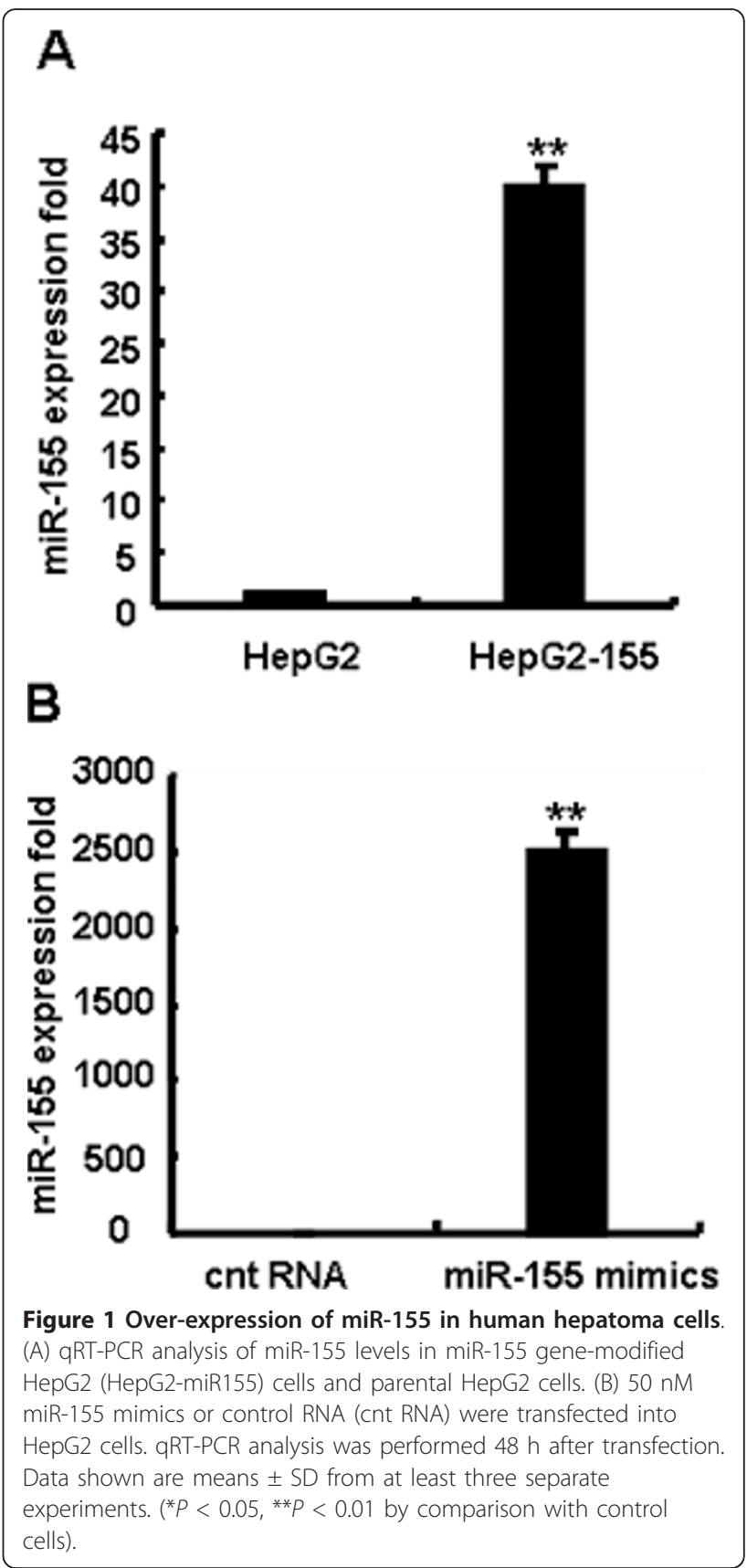


the level of miR-155 in HepG2 cells transfected with miR-155 mimics was much higher ( 2500 folds $)$ than that in HepG2 cells transfected with control RNA $(P<$ $0.01)$.

miR-155 slightly increased the growth of human hepatoma cells

MiR-155 has been reported to be over-expressed in many solid tumor cells and functions as 'oncomir' $[6,14]$. So, we identified whether miR-155 could regulate human hepatoma cell proliferation in vitro. Until cultured for 4 days, it showed a slight increase in the proliferation of miR-155 over-expressed HepG2 cells, especially HepG2 cells transfected with miR-155 mimics, when compared to that of control cells (Figure 2A and 2B), indicating that miR-155 displays different roles in diverse cells.

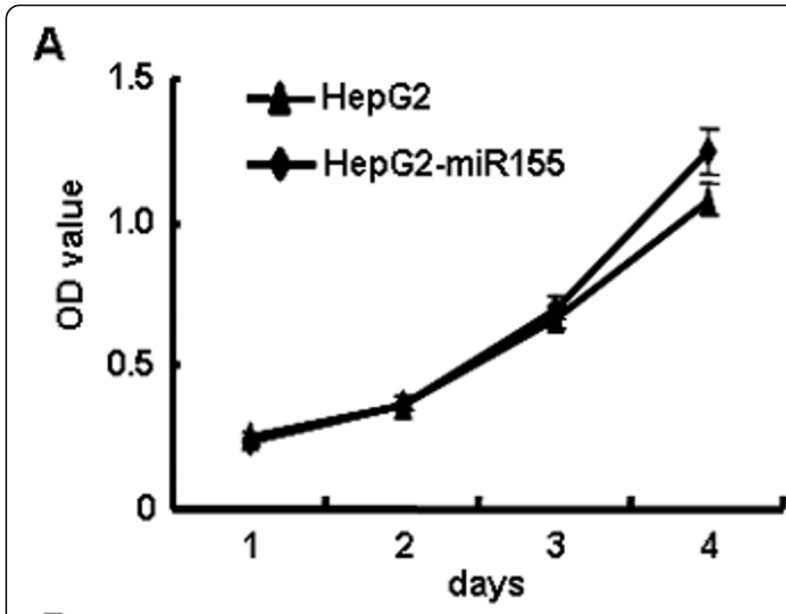

B

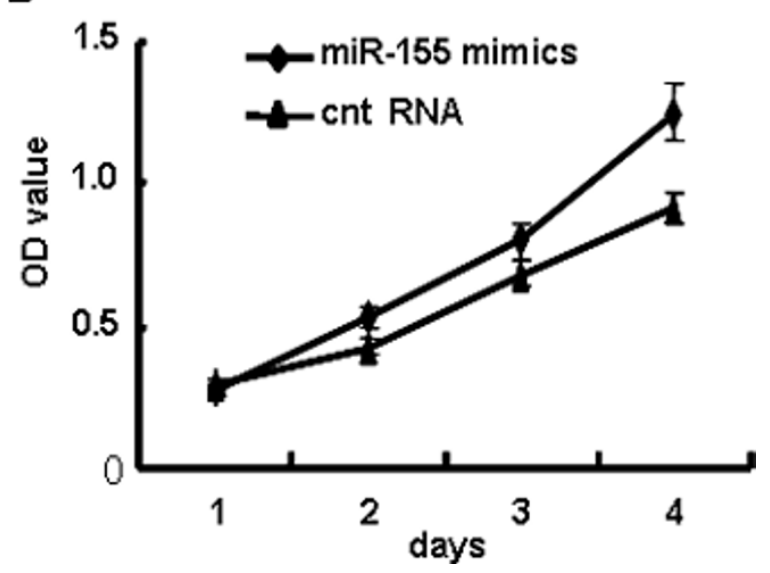

Figure 2 miR-155 slightly increased the growth of human hepatoma cells. (A) HepG2 and HepG2-miR155 cell growth were determined by MTT assay. (B) HepG2 cells were transfected with 50 nM miR-155 mimics or control RNA followed by MTT assay $6 \mathrm{~h}$ after transfection. These experiments were repeated at least 3 times.
Upregulation of IFN-inducible antiviral genes by miR-155 over-expression in human hepatoma cells

The type I interferon dependent cytokines are recognized as crucial components during the innate immune response and the first line of antiviral defense. In the studies of gene knockout mice, ISG15, Mx proteins (MxA), 2'-5' oligoadenylate synthetase (OAS) and APOBEC3 family, such as APOBEC3B (A3B) have been validated as antiviral effectors [15-17]. Therefore, the expression of MxA, ISG15, OAS-1, A3B and interferon regulatory factor3 (IRF3) in HepG2 cells were evaluated by RT-PCR (Figure 3A and $3 C)$. We found that the mRNA levels of MxA and ISG15 in miR-155 over-expressed HepG2 cells were increased about $30 \%$ and $40 \%$ respectively, while the levels of A3B, OAS1 and IRF3 were not significantly changed (Figure 3B and 3D). Similar results were observed in another human hepatoma cell line H7402 (Figure 3E and 3F). Western blot analysis showed that ISG15 protein levels were increased as well (Figure 3G and 3H).

miR-155 post-transcriptionally regulated SOCS1 and activated JAK/STAT signaling pathway in human hepatoma cells

Earlier studies indicated that miR-155 and SOCS1 interacted in regulatory $\mathrm{T}$ cells, macrophages and human breast cancer cells [18-20]. SOCS1 has been identified to negatively regulate various immune responses and signaling pathways, including the IFN signaling [21,22]. Then we examined whether the translation level of SOCS1 was regulated by miR-155 in human hepatoma cells. Western blot assays indicated that the SOCS1 protein level was reduced significantly in HepG2 cells overexpressing miR-155 compared with the relative control (Figure 4B, D), while the mRNA level of SOCS1 was not obviously changed (Figure 4A).

SOCS1 has been known to inhibit JAK phosphorylation and subsequent binding, phosphorylation and activation of STATs. In the absence of SOCS1, type I IFNinduced STAT1 activation is prolonged, and the antiviral and pro-inflammatory effect of these elements are amplified [21,22]. As SOCS1 is suppressed by miR-155, we speculated that miR-155 over-expression in human hepatoma cells may play a role in JAK/STAT signaling. As expected, p-STAT1 and p-STAT3 were constitutively activated in HepG2 cells over-expressing miR-155 (Figure 4C, E). Similar results were observed in H7402 cells (Figure 4F, G). These findings revealed that miR-155 post-transcriptionally regulated SOCS1 expression and activated JAK/STAT signaling in human hepatoma cells.

Augmented type I IFN signaling by miR-155 overexpression in human hepatoma cells

We examined type I IFN production in HepG2 cells and found no significant difference in the mRNA levels of 


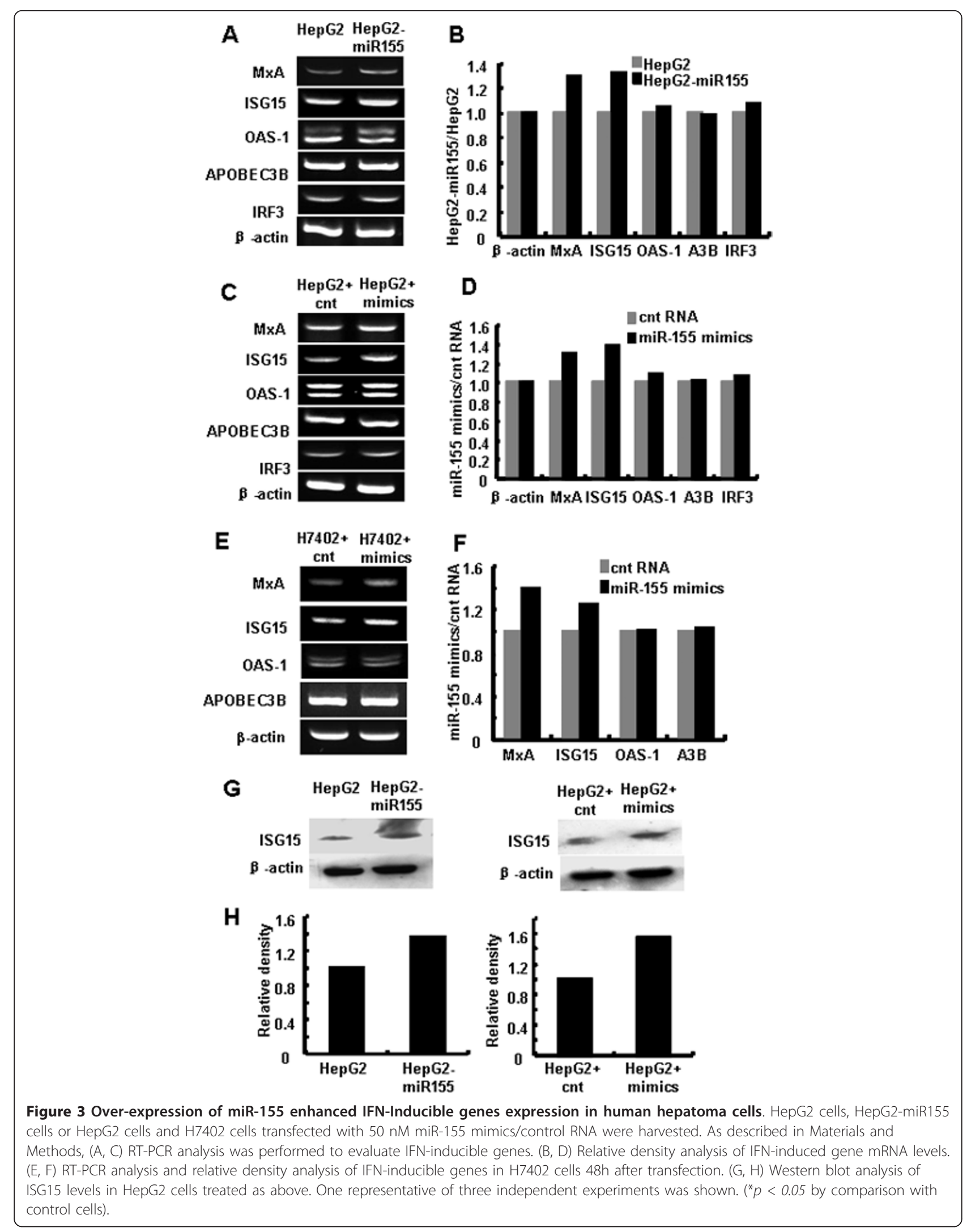




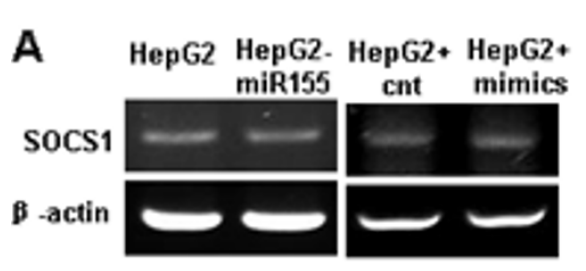

B
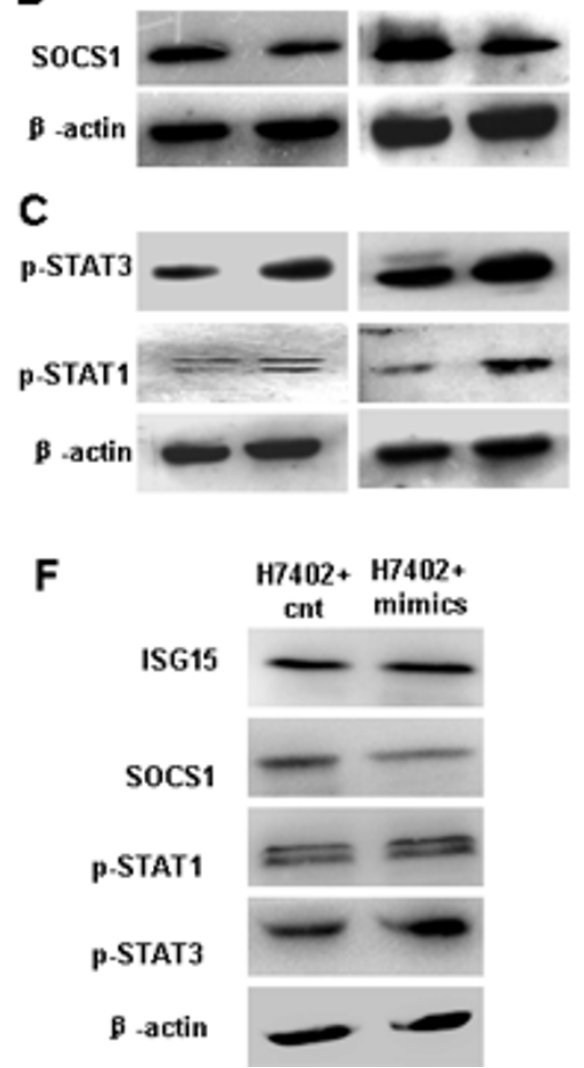

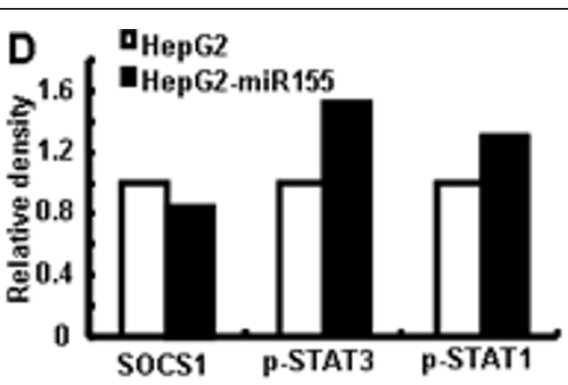

$\mathbf{E}$
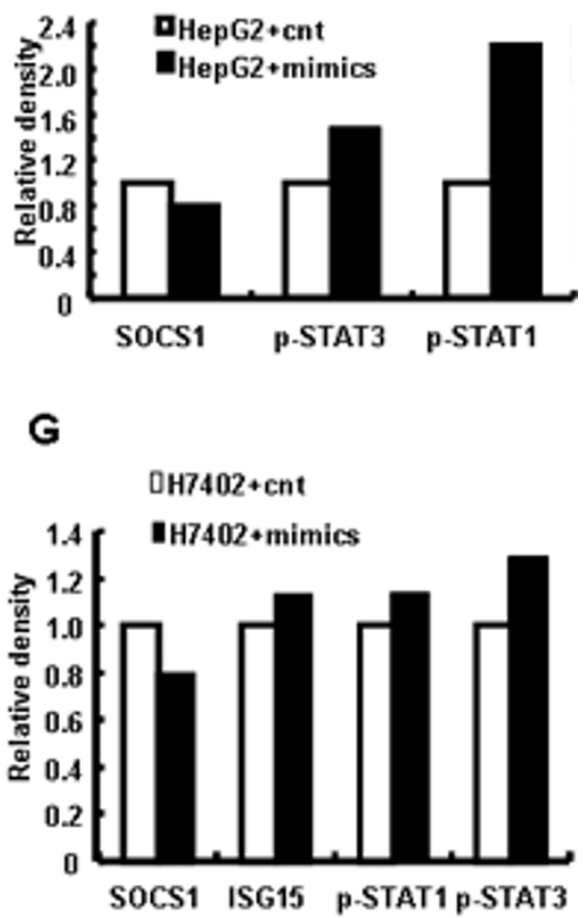

Figure 4 miR-155 post-transcriptionally inhibited SOCS1 and activated JAK/STAT signaling pathway in human hepatoma cells. (A) Analysis of SOCS1 mRNA levels by RT-PCR. Total RNA was extracted from HepG2 and HepG2-miR155 cells, and HepG2 cells transfected with 50 nM miR-155 mimics or control RNA. (B) SOCS1, (C) p-STAT1 and p-STAT3 protein levels in cells above were tested by western blot analysis. (D, E) Relative density analysis of the IFN-induced gene protein levels. (F) Western blot analysis of ISG15, SOCS1, p-STAT1 and p-STAT3 protein levels in H7402 cells were performed 48h after transfection. (G) Relative density analysis of the IFN-induced gene protein levels in H7402. One

representative of three independent experiments was shown.

either IFN- $\alpha$ or IFN- $\beta$ when miR-155 was overexpressed (data not shown). We next analyzed the expression of IFN inducible antiviral genes in response to the treatment of IFN- $\alpha 2 \alpha$. As shown in Figure 5A and $5 \mathrm{~B}$, antiviral genes expressed in HepG2 cells treated with miR-155 mimics were higher than that in control cells. Moreover, the expression of SOCS1 was decreased, while the expression of p-STAT1 and p-STAT3 were increased in HepG2 cells transfected with miR-155 mimics after IFN- $\alpha 2 \alpha$ treatment (Figure $5 \mathrm{C}$ and 5D). These data suggested that over-expression of miR-155 could promote type I IFN signaling and increase IFN- inducible antiviral gene expression in human hepatoma cells.

\section{Over-expression of miR-155 inhibited HBV in human hepatoma cells}

Human hepatitis B virus (HBV) induces hepatitis and is closely associated with the incidence of human hepatoma cancer [9]. HBV was shown to be very efficient at inhibiting the IFN signaling pathway [23-25]. So, we further assessed whether over-expression of miR-155 could attenuate HBV infection. PAAV/HBV1.2 plasmid and miR-155 mimics, or control RNA were 

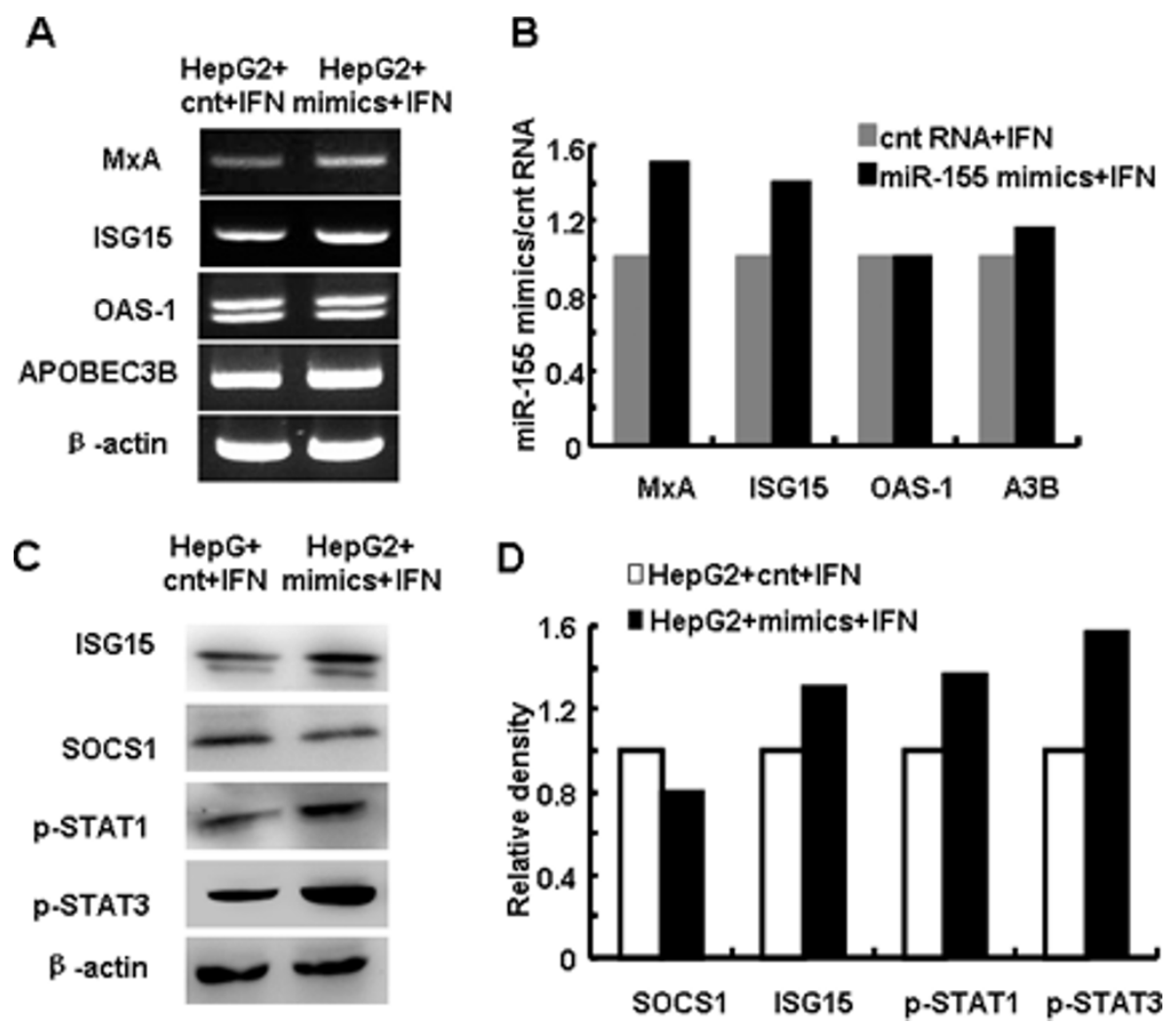

Figure 5 Augmented type I IFN signaling by miR-155 over-expression in human hepatoma cells. (A) HepG2 cells transfected with 50 nM miR-155 mimics/control RNA were stimulated by $500 \mathrm{U} / \mathrm{mL}$ IFN- $\alpha 2 \alpha$ for 12 h. RT-PCR analysis was performed to evaluate IFN-inducible genes. (B) Relative density analysis of the IFN-inducible genes. (C) SOCS1, p-STAT1 and p-STAT3 protein levels in cells above were tested by western blot analysis. (D) Relative density analysis of the signaling transduction protein levels in HepG2 cells. One representative of three independent experiments was shown.

cotransfected into HepG2 cells, then expression levels of HBV X gene $(\mathrm{HBx})$ were examined by RT-PCR. As shown in Figure 6A and 6B, HBx level was reduced $12 \%$ in HepG2 cells transfected with miR-155 mimics compared with HepG2 cells transfected with control RNA $(P<0.05)$ (Figure 6B right), but there was no significant difference between HepG2 and HepG2-miR155 cells (Figure 6B left). One explanation for this result is that the level of miR-155 in HepG2 cells transfected with miR-155 mimics was much higher than that in HepG2-miR155 cells (Figure 1A and 1B), so we speculated that the antiviral effect of miR-155 depended on its level.

Since miR-155 affect type I IFN signaling pathway, we further addressed whether miR-155 could change the anti-HBV efficiency of exogenous IFN, but as shown in Figure $6 \mathrm{C}$ and 6D, the levels of HBV X gene in HepG2 cells treated with miR-155 mimics or control RNA showed no significant difference in the presence of IFN$\alpha 2 \alpha$. Type I IFN can inhibit HBV replication intensively in some HBV-bore cell models based on HBV genome transfection, but miRNA always shows more delicate regulation on virus life cycle than that of siRNA which directly degrade virus RNA. So, IFN- $\alpha 2 \alpha$ may exert much stronger controlling effects on HBV in hepatocytes than that of miR-155 itself. Taken together, these results indicate that miR-155 exhibited mild anti-HBV effect in human hepatoma cells.

\section{Discussion}

To date, only few publications reveal the roles of miR155 in viral infection. Viruses can utilize host miRNAs as survival mechanisms, and even encode viral mimics of host miRNAs. One such miR-155 mimic has been found in Kaposi's-sarcoma-associated herpesvirus (KSHV) $[7,26,27]$. The infection of primary human B lymphocytes with the Epstein-Barr virus (EBV) leads to a sustained elevation of miR-155 expression and contributes to EBV immortalization [28]. These studies suggest that miR-155, encoded by viruses or upregulated by viral infection, contributes to viral-mediated infection via modulating different transcription factors and NF- $\kappa \mathrm{B}$ components [14,29-31]. However, a recent research reveals that miR-155 expression is also upregulated by 


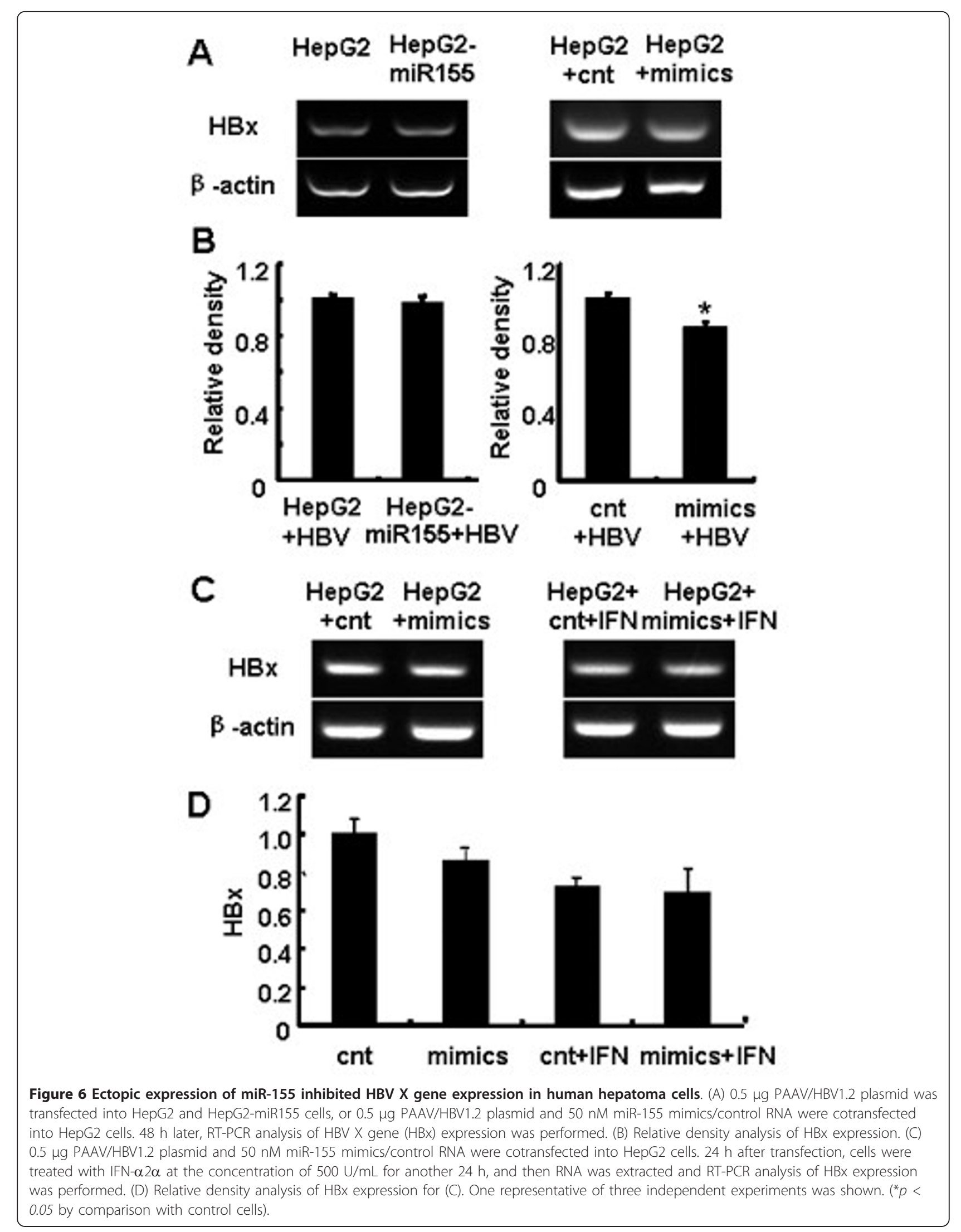


VSV infection in murine macrophages, but the induced miR-155 feedback attenuates the viral replication through enhancing type I IFN signaling by targeting SOCS1 [32]. The biological function of miR-155 in hepatoma cells is still unclear.

HBV is a hepatotropic, enveloped DNA virus, causes acute and always chronic HBV infection and leads to hepatoma fibrosis, cirrhosis and eventually hepatocellular carcinoma [9]. Recent studies have revealed the role of several miRNAs in intricate network of hepatocyteHBV interactions. Early in 2007, Ai-Guang Guo group firstly predicted that HBV may encode one miRNA [33], but miRBase didn't accept it as a formal member until now. Many host miRNAs were forecasted to bind to both HBV genome and host gene by different laboratories [34-36]. By the end of the year 2010, miR-199a-3p and miR-210 were found to suppress HBsAg expression by directly targeting the HBV $\mathrm{S}$ protein coding region and pre-S1 region, respectively [37]; miR125a-5p was then shown to interfere with the viral translation, downregulating the expression of the surface antigen [38], while miR-1 increases HBV transcription by upregulating farnesoid $\mathrm{X}$ receptor $\alpha$ (FXRA), a nuclear receptors binding to the HBV core promoter and regulating HBV transcription and replication. Here, we showed that miR-155 also exhibited mild anti-HBV effect in human hepatoma cells through promoting JAK/STAT signaling pathway and enhancing innate antiviral immunity. Our work reveals a new intricate physiological interplay between miRNAs and HBV replication.

Many evidence shows that miR-155 is over-expressed in a number of neoplastic diseases and plays a significant role in the process of carcinogenesis, acting as an oncomir [39-42]. In this paper, we found that miR-155 expression was very low in HepG2 cells. Though ectopic expression of miR-155 could promote HepG2 cell proliferation, the extent was much weaker than that in other cell lines, such as breast cancer cells [20], which is favorable for miR-155 to be used in antiviral therapeutics without significantly affecting host cell proliferation. These findings indicated that miR-155 play different roles in diverse cells.

In this study, we notice that not all the IFN-induced genes are equally induced by miR-155 over-expression. Since they are all regulated by JAK/STAT signaling and the downstream of type I IFN signaling pathway [43], there must be some other mechanisms to regulate their expression. Though expressions of MxA and ISG15 were elevated by miR-155, their levels were only increase by less than $50 \%$ (Figure $3 \mathrm{~B}$ and $3 \mathrm{D}$ ), and $\mathrm{HBx}$ was only reduced by $\sim 10 \%$ (Figure $6 \mathrm{~B}$ ), which is different from a recent report, where VSV replication was largely suppressed by miR-155 in macrophages [32]. This may due to the difference of host cells and viruses. The potency of one miRNA in hepatocytes would be rather weaker than that in lymphocytes, and HBV has its own properties.

Overall, although the anti-HBV effect mediated by miR-155 is lower compared with its anti-VSV effect in macrophages, it might benefit to anti-HBV when combine with other antiviral therapeutics. The detail mechanisms will be further investigated in the future.

\section{Conclusions}

miR-155, as a positive regulator of JAK/STAT signaling by targeting SOCS1, increases the expression of IFNinducible antiviral genes and enhances innate antiviral immunity in human hepatoma cells. Further more, overexpression of miR-155 exhibited mild anti-HBV effect in human hepatoma cells.

\section{Materials and methods \\ Cell line and cell culture}

Human hepatocellular carcinoma cell lines HepG2 and H7402 conserved in our laboratory, were cultured in DMEM (GIBCO/BRL, Grand Island, N.Y. USA) containing $10 \% \mathrm{FBS}$ in a humidified incubator with $5 \% \mathrm{CO}_{2}$ at $37^{\circ} \mathrm{C}$.

\section{Vector construction}

Total genomic DNA was extracted from HepG2 cells using Genomic DNA Extraction Kit purchased from Sangon Biotech (Shanghai, China) according to the manufacturer's instructions. The miR-155 expression cassette containing the human miR-155 hairpin sequence and flanking regions was amplified from the genomic DNA using the pri-miR-155 primers (Table 1). The cassette was then inserted into an expression vector (pcDNA3). The resulting construct was termed pcDNA3-hsa-miR-155. The construct was confirmed by DNA sequencing. PAAV/HBV1.2 consists of a greater than genome-length HBV fragment that encodes all the proteins of HBV including large, middle and small surface proteins, polymerase protein, $\mathrm{X}$ protein, and core and pre-core proteins. It can initiate HBV replication after being transfected into hematoma cell lines [44].

\section{RNA oligonucleotide and cell transfection}

miR-155 mimic (dsRNA oligonucleotides), used for the over-expression of miR-155 in hepatoma cells, and negative control RNA (dsRNA oligonucleotides), used as the matched control, were purchased from Shanghai GenePharma Co., Ltd (Shanghai, China). Transfection was performed using Lipofectamine 2000 (Invitrogen, Carlsbad, CA, USA) according to the manufacturer's instructions. For transfection of the RNA oligonucleotides, $50 \mathrm{nM}$ miRNA mimics or control RNA were used. 
Table 1 Primers used for RT-PCR reactions

\begin{tabular}{|c|c|c|c|c|}
\hline Transcripts & Product size(bp) & Sequences $\left(5^{\prime}-3^{\prime}\right)$ & $\operatorname{Tm}\left({ }^{\circ} \mathrm{C}\right)$ & PCR cycle \\
\hline$\beta$-actin & 540 & $\begin{array}{l}\text { GTGGGGCGCCCCAGGCACCA } \\
\text { CTCCTTAATGTCACGCACGATTTC }\end{array}$ & $60^{\circ} \mathrm{C}$ & 28 cycles \\
\hline SOCS1 & 301 & $\begin{array}{l}\text { CACGCACTTCCGCACATTCC } \\
\text { TCCAGCAGCTCGAAGAGGCA }\end{array}$ & $55^{\circ} \mathrm{C}$ & 35 cycles \\
\hline MxA & 581 & $\begin{array}{l}\text { ACCAGCTGAGCCTGTCCGAAGCCC } \\
\text { CCGGACCATATCCGTCACGGTG }\end{array}$ & $60^{\circ} \mathrm{C}$ & 35 cycles \\
\hline ISG15 & 294 & $\begin{array}{l}\text { GGTGGACAAATGCGACG } \\
\text { ATGCTGGTGGAGGCCCTTAG }\end{array}$ & $60^{\circ} \mathrm{C}$ & 28 cycles \\
\hline OAS-1 & $\begin{array}{l}356 \\
454\end{array}$ & $\begin{array}{l}\text { ACACATTTCAACACAGCCCA } \\
\text { TGCAGGTCCAGTCCTCTTCT }\end{array}$ & $60^{\circ} \mathrm{C}$ & 35 cycles \\
\hline APOBEC 3B & 981 & $\begin{array}{l}\text { GTTGTATCCTGGACCCCCT } \\
\text { GAGATGGTGGTGAACGGTCT }\end{array}$ & $60^{\circ} \mathrm{C}$ & 30 cycles \\
\hline $\mathrm{HBx}$ & 250 & $\begin{array}{l}\text { CCGTCTGTGCCTTCTCATCTGC } \\
\text { CCTCCGACATCCGTATITAACCA }\end{array}$ & $60^{\circ} \mathrm{C}$ & 28 cycles \\
\hline pri-miR-155 & 307 & $\begin{array}{l}\text { AGGTGGCACAAACCAGGAA } \\
\text { GTTGAACATCCCAGTGACCAG }\end{array}$ & $58^{\circ} \mathrm{C}$ & 38 cycles \\
\hline
\end{tabular}

Establishment of miR-155 stably over-expressed cells pcDNA3-hsa-miR-155 plasmid $(0.4 \mu \mathrm{g})$ were transfected into HepG2 cells, and then $200 \mu \mathrm{g} / \mathrm{mL}$ G418 (GIBCO/ BRL) was added $48 \mathrm{~h}$ after transfection, and the cells stably over-expressing miR-155 were selected for two weeks until clones form.

\section{Reverse Transcriptase Polymerase Chain Reaction (RT- PCR) assay}

RNA was extracted from HepG2 cells $\left(5 \times 10^{5}\right)$ by Trizol Reagent (Invitrogen, Carlsbad, CA, USA) according to the protocol provided by the manufacturer. The concentration and quality of the extracted RNA were determined by measuring light absorbance at $260 \mathrm{~nm}\left(\mathrm{~A}_{260}\right)$ at a ratio of $\left(\mathrm{A}_{260} / \mathrm{A}_{280}\right)$. Total RNA was reverse transcribed to cDNA and standard PCR reaction was performed in a total volume of $25 \mu \mathrm{l}$ as described previously [45]. The PCR products were electrophoresed on $2 \%$ agarose gels and the relative light intensities of bands were analyzed by AlphaEaseFC software. The PCR primers and their product lengths are listed in Table 1 and were synthesized by the Beijing Genomics Institute (Beijing, China).

\section{Quantitative reverse transcription-PCR assay}

The miR-155 level was quantified by quantitative reverse transcription-PCR (qRT-PCR) using specific BulgeLoop $^{\mathrm{TM}}$ miRNA qRT-PCR Primer purchased from Guangzhou Ribobio (Guangzhou, China) with U6 small nuclear RNA as an internal normalized reference.

\section{Cell proliferation assay}

All cellular growth assays were performed in 96-well plates $\left(6 \times 10^{3}\right.$ cells/well). HepG2 cells were transfected with $50 \mathrm{nM}$ miR-155 mimics or control RNA. Four hours after transfection, equal numbers of viable cells were seeded in 96-well plates and incubated for indicated time. Next, $20 \mu \mathrm{l}$ MTT $(10 \mathrm{mg} / \mathrm{ml}$, Sigma, St Louis, MO, USA) solution was added to each well and the plates were incubated for additional $4 \mathrm{~h}$ at $37^{\circ} \mathrm{C}$. After centrifugation, MTT solution was then removed, and $200 \mu \mathrm{l}$ dimethyl-sulfoxide (DMSO; Sigma, St Louis, MO, USA) was added to each well to solubilize the formazan crystals. Absorbance was then read at a wavelength of $570 \mathrm{~nm}$ on a scanning multiwell spectrophotometer.

\section{Western blot}

Cells were harvested $48 \mathrm{~h}$ after seeded or transfection and homogenized in lysis buffer (30 mM Tris, $\mathrm{pH} 7.5$, $150 \mathrm{mM}$ sodium chloride, $1 \mathrm{mM}$ PMSF, $1 \mathrm{mM}$ sodium orthovanadate, $1 \%$ Nonidet P-40, and $10 \%$ glycerol) at $4^{\circ}$ $\mathrm{C}$, vortexed, and centrifuged at $13,000 \mathrm{~g}$ at $4^{\circ} \mathrm{C}$ for 30 min. The supernatants were mixed in Laemmli loading buffer, boiled for $5 \mathrm{~min}$, and then subjected to SDSPAGE. After electrophoresis, proteins were transferred onto nitrocellulose membranes and blotted against primary Abs for $12 \mathrm{~h}$. Membranes were washed with $0.1 \%$ (v/v) Tween 20 in TBS and incubated with a 1:2000 dilution of HRP conjugated secondary Abs for $1 \mathrm{~h}$. Protein bands were visualized by Immobilon Western Chemiluminescent HRP Sbustrate (Millipore Corporation, Billerica, U.S.A). Antibodies for SOCS1, ISG15 and pSTAT1 were from Cell Signaling Technology (New England BioLabs Inc.); antibody for phospho-STAT3 was from Bioworld Technology, Inc. (Minneapolis, Minnesota, USA); and antibody for $\beta$-actin was from Santa Cruz Biotechnology (Santa Cruz, CA, USA).

\section{Statistical analyzes}

All data are expressed as mean \pm SD and accompanied by at least three distinct experiments. Statistical analysis 
was performed using SPSS software (version 10.0; SPSS Inc., USA) and $p<0.05$ were considered statistically significant.

\section{Acknowledgements}

This work was supported by grants from the National Natural Science Foundation of China (30972962, 30901307) and the Ministry of Science and Technology of China (2006CB504303;2007AA021109; 008ZX10002-008).

\section{Authors' contributions}

CS carried out most of the experiments and wrote the manuscript. $\mathrm{ZH}$ participated in project design and edit the manuscript. CZ and ZT provided useful advices for the project. JZ is the project leader and was involved in project design, data analysis and finalization of the manuscript. All authors read and approved the final manuscript.

\section{Competing interests}

The authors declare that they have no competing interests.

Received: 13 April 2011 Accepted: 18 July 2011 Published: 18 July 2011

\section{References}

1. Baltimore D, Boldin MP, O'Connell RM, Rao DS, Taganov KD: MicroRNAs: new regulators of immune cell development and function. Nat Immunol 2008, 9(8):839-845.

2. O'Connell RM, Rao DS, Chaudhuri AA, Baltimore D: Physiological and pathological roles for microRNAs in the immune system. Nat Rev Immunol 2010, 10(2):111-122.

3. Gottwein E, Cullen BR: Viral and cellular microRNAs as determinants of viral pathogenesis and immunity. Cell Host Microbe 2008, 3(6):375-387.

4. Sullivan CS, Grundhoff AT, Tevethia S, Pipas JM, Ganem D: SV40-encoded microRNAs regulate viral gene expression and reduce susceptibility to cytotoxic T cells. Nature 2005, 435(7042):682-686.

5. O'Connell RM, Taganov KD, Boldin MP, Cheng G, Baltimore D: MicroRNA155 is induced during the macrophage inflammatory response. Proc Natl Acad Sci USA 2007, 104(5):1604-1609.

6. Faraoni I, Antonetti FR, Cardone J, Bonmassar E: miR-155 gene: a typical multifunctional microRNA. Biochim Biophys Acta 2009, 1792(6):497-505.

7. Skalsky RL, Samols MA, Plaisance KB, Boss IW, Riva A, Lopez MC, Baker HV Renne R: Kaposi's sarcoma-associated herpesvirus encodes an ortholog of miR-155. J Virol 2007, 81(23):12836-12845

8. Zhao Y, Yao Y, Xu H, Lambeth L, Smith LP, Kgosana L, Wang X, Nair V: A functional MicroRNA-155 ortholog encoded by the oncogenic Marek's disease virus. J Virol 2009, 83(1):489-492.

9. Tiollais P, Charnay P, Vyas GN: Biology of hepatitis B virus. Science 1981, 213(4506):406-411.

10. Seeger C, Mason WS: Hepatitis B virus biology. Microbiol Mol Biol Rev 2000, 64(1):51-68.

11. Rehermann B, Nascimbeni M: Immunology of hepatitis B virus and hepatitis C virus infection. Nat Rev Immunol 2005, 5(3):215-229.

12. Min $\mathrm{H}$, Chen $\mathrm{CZ}$ : Methods for analyzing microRNA expression and function during hematopoietic lineage differentiation. Methods Mol Biol 2006, 342:209-227

13. Wang Z: The guideline of the design and validation of MiRNA mimics. Methods Mol Biol 2011, 676:211-223.

14. Tili E, Croce CM, Michaille JJ: miR-155: on the crosstalk between inflammation and cancer. Int Rev Immunol 2009, 28(5):264-284.

15. Cullen BR: Role and mechanism of action of the APOBEC 3 family of antiretroviral resistance factors. J Virol 2006, 80(3):1067-1076.

16. Sadler AJ, Williams BR: Interferon-inducible antiviral effectors. Nat Rev Immunol 2008, 8(7):559-568.

17. Genin P, Vaccaro A, Civas A: The role of differential expression of human interferon-a genes in antiviral immunity. Cytokine Growth Factor Rev 2009 20(4):283-295.

18. Androulidaki A, lliopoulos D, Arranz A, Doxaki C, Schworer S, Zacharioudaki V, Margioris AN, Tsichlis PN, Tsatsanis C: The kinase Akt1 controls macrophage response to lipopolysaccharide by regulating microRNAs. Immunity 2009, 31(2):220-231.
19. Lu LF, Thai TH, Calado DP, Chaudhry A, Kubo M, Tanaka K, Loeb GB, Lee H, Yoshimura A, Rajewsky K, Rudensky AY: Foxp3-dependent microRNA155 confers competitive fitness to regulatory $T$ cells by targeting SOCS 1 protein. Immunity 2009, 30(1):80-91.

20. Jiang S, Zhang HW, Lu MH, He XH, Li Y, Gu H, Liu MF, Wang ED: MicroRNA-155 functions as an OncomiR in breast cancer by targeting the suppressor of cytokine signaling 1 gene. Cancer Res 2010, 70(8):3119-3127.

21. Davey GM, Heath WR, Starr R: SOCS1: a potent and multifaceted regulator of cytokines and cell-mediated inflammation. Tissue Antigens 2006, 67(1):1-9.

22. Kisseleva T, Bhattacharya S, Braunstein J, Schindler CW: Signaling through the JAK/STAT pathway, recent advances and future challenges. Gene 2002, 285(1-2):1-24.

23. Christen V, Duong F, Bernsmeier C, Sun D, Nassal M, Heim MH: Inhibition of alpha interferon signaling by hepatitis B virus. J Virol 2007, 81(1):159-165

24. Li J, Chen F, Zheng M, Zhu H, Zhao D, Liu W, Liu W, Chen Z: Inhibition of STAT1 methylation is involved in the resistance of hepatitis $B$ virus to Interferon alpha. Antiviral Res 2010, 85(3):463-469.

25. Fernandez M, Quiroga JA, Carreno V: Hepatitis B virus downregulates the human interferon-inducible MxA promoter through direct interaction of precore/core proteins. J Gen Virol 2003, 84(Pt 8):2073-2082.

26. McClure LV, Sullivan CS: Kaposi's sarcoma herpes virus taps into a host microRNA regulatory network. Cell Host Microbe 2008, 3(1):1-3.

27. Gottwein E, Mukherjee N, Sachse C, Frenzel C, Majoros WH, Chi JT, Braich R, Manoharan M, Soutschek J, Ohler U, Cullen BR: A viral microRNA functions as an orthologue of cellular miR-155. Nature 2007, 450(7172):1096-1099.

28. Lu F, Weidmer A, Liu CG, Volinia S, Croce CM, Lieberman PM: Epstein-Barr virus-induced miR-155 attenuates NF-kappaB signaling and stabilizes latent virus persistence. J Virol 2008, 82(21):10436-10443.

29. Horikawa T, Yoshizaki T, Kondo S, Furukawa M, Kaizaki Y, Pagano JS: Epstein-Barr Virus latent membrane protein 1 induces Snail and epithelial-mesenchymal transition in metastatic nasopharyngeal carcinoma. Br J Cancer 2011, 104(7):1160-1167

30. Rahadiani N, Takakuwa T, Tresnasari K, Morii E, Aozasa K: Latent membrane protein-1 of Epstein-Barr virus induces the expression of B-cell integration cluster, a precursor form of microRNA-155, in B lymphoma cell lines. Biochem Biophys Res Commun 2008, 377(2):579-583.

31. Yin Q, McBride J, Fewell C, Lacey M, Wang X, Lin Z, Cameron J, Flemington EK: MicroRNA-155 is an Epstein-Barr virus-induced gene that modulates Epstein-Barr virus-regulated gene expression pathways. J Virol 2008, 82(11):5295-5306

32. Wang P, Hou J, Lin L, Wang C, Liu X, Li D, Ma F, Wang Z, Cao X: Inducible microRNA-155 feedback promotes type I IFN signaling in antiviral innate immunity by targeting suppressor of cytokine signaling $1 . \mathrm{J}$ Immunol 2010, 185(10):6226-6233.

33. Jin WB, Wu FL, Kong D, Guo AG: HBV-encoded microRNA candidate and its target. Comput Biol Chem 2007, 31(2):124-126.

34. Mizuguchi $Y$, Mishima T, Yokomuro S, Arima Y, Kawahigashi $Y$, Shigehara $K$, Kanda T, Yoshida H, Uchida E, Tajiri T, Takizawa T: Sequencing and bioinformatics-based analyses of the microRNA transcriptome in hepatitis B-related hepatocellular carcinoma. PLoS One 2011, 6(1):e15304

35. Wu FL, Jin WB, Li JH, Guo AG: Targets for human encoded microRNAs in HBV genes. Virus Genes 2011, 42(2):157-161.

36. Li LM, Hu ZB, Zhou ZX, Chen X, Liu FY, Zhang JF, Shen HB, Zhang CY, Zen $\mathrm{K}$ : Serum microRNA profiles serve as novel biomarkers for HBV infection and diagnosis of HBV-positive hepatocarcinoma. Cancer Res 2010, 70(23):9798-9807.

37. Zhang GL, Li YX, Zheng SQ, Liu M, Li X, Tang H: Suppression of hepatitis B virus replication by microRNA-199a-3p and microRNA-210. Antiviral Res 2010, 88(2):169-175.

38. Potenza N, Papa U, Mosca N, Zerbini F, Nobile V, Russo A: Human microRNA hsa-miR-125a-5p interferes with expression of hepatitis $B$ virus surface antigen. Nucleic Acids Res 2011.

39. Greither $T$, Grochola LF, Udelnow A, Lautenschlager C, Wurl P, Taubert H: Elevated expression of microRNAs 155, 203, 210 and 222 in pancreatic tumors is associated with poorer survival. Int J Cancer 2010, 126(1):73-80.

40. Eis PS, Tam W, Sun L, Chadburn A, Li Z, Gomez MF, Lund E, Dahlberg JE: Accumulation of miR-155 and BIC RNA in human B cell lymphomas. Proc Natl Acad Sci USA 2005, 102(10):3627-3632. 
41. Esquela-Kerscher A, Slack FJ: Oncomirs - microRNAs with a role in cancer. Nat Rev Cancer 2006, 6(4):259-269.

42. Iorio MV, Ferracin M, Liu CG, Veronese A, Spizzo R, Sabbioni S, Magri E, Pedriali M, Fabbri M, Campiglio M, Ménard S, Palazzo JP, Rosenberg A, Musiani P, Volinia S, Nenci I, Calin GA, Querzoli P, Negrini M, Croce CM: MicroRNA gene expression deregulation in human breast cancer. Cancer Res 2005, 65(16):7065-7070.

43. Fensterl V, Sen GC: Interferons and viral infections. Biofactors 2009, 35(1):14-20.

44. Huang LR, Wu HL, Chen PJ, Chen DS: An immunocompetent mouse model for the tolerance of human chronic hepatitis $B$ virus infection. Proc Natl Acad Sci USA 2006, 103(47):17862-17867.

45. Zhang J, Sun R, Wei H, Zhang J, Tian Z: Characterization of interleukin-15 gene-modified human natural killer cells: implications for adoptive cellular immunotherapy. Haematologica 2004, 89(3):338-347.

doi:10.1186/1743-422X-8-354

Cite this article as: Su et al.: Ectopic expression of microRNA-155 enhances innate antiviral immunity against HBV infection in human hepatoma cells. Virology Journal 2011 8:354.

\section{Submit your next manuscript to BioMed Central} and take full advantage of:

- Convenient online submission

- Thorough peer review

- No space constraints or color figure charges

- Immediate publication on acceptance

- Inclusion in PubMed, CAS, Scopus and Google Scholar

- Research which is freely available for redistribution

Submit your manuscript at www.biomedcentral.com/submit 